\title{
Gorontalo
}

Journal of Government and Political Studies

Volume 4 - NO. 1 - Maret 2021

P-ISSN: 2614-2120 E-ISSN: 2614-2104

\section{NGOs and Child Marriage Problem in Indonesia: Analysis of Issues, Strategies and Networks}

\author{
Adelita Lubis ${ }^{1}$ \\ Aswin Baharuddin ${ }^{2}$ \\ Andi Meganingratna ${ }^{3}$ \\ Mia Aulina Lubis 4 \\ 1,3Universitas Fajar \\ Jalan Prof. Abdurahman Basalamah No 101, Makassar \\ 2Universitas Hasanuddin \\ Jalan Perintis Kemerdekaan KM 10, Makassar \\ ${ }^{4}$ Universitas Sumatera Utara \\ Jalan Abdul Hakim No. 1, Medan \\ adelitalubis@gmail.com
}

Received: 07th January 2021; Revised: 17th March 2021;

Accepted: 19th March 2021;

\begin{abstract}
The phenomenon of increasing early childhood marriage has put Indonesia in the spotlight of the UN Committee on the Rights of the Child. Indonesia is listed as the country with the 7th highest number of early childhood marriages internationally and is ranked 2nd in ASEAN. This phenomenon makes various parties, both from government and nongovernment, to respond to this problem. This study aims to analyze the strategies used by non-government actors in the prevention of early childhood marriage. The case raised was the role of the Legal Aid Institute for the Indonesian Women's Association for Justice (LBH APIK) in South Sulawesi. In particular, this study tries to analyze the LBH Apik international network development model. Initial information shows that for implementing this advocacy agenda, LBH Apik collaborates with International Non-Governmental Organizations (NGOs) or International Non-Governmental Organizations (INGO), namely OXFAM. This is a qualitative research, data is collected by in-depth interviews and source documents._This study found that; First, LBH Apik's activities in efforts to prevent child marriage can be categorized as an effort by NGOs to implement human security values. Second, the strategies adopted by LBH Apik show that the changes required are transformative because they encourage changes in the social structure that make the position of girls very vulnerable. Third, local, national and international partnerships with LBH Apik are built on a collective identity as the party fighting to prevent child marriage.
\end{abstract}

Keywords: child marriage; international NGOs; LBH APIK; OXFAM

\begin{abstract}
ABSTRAK
Fenomena peningkatan pernikahan anak usia dini membuat Indonesia menjadi sorotan Komite Hak Anak PBB. Indonesia tercatat sebagai negara dengan jumlah pernikahan anak usia dini tertinggi ke-7 secara internasional dan menduduki peringkat ke-2 di ASEAN. Fenomena tersebut membuat beragam pihak baik dari pemerintah maupun non-pemerintah merespon permasalahan tersebut. Penelitian ini bertujuan untuk menganalisis strategi yang digunakan oleh aktor non-pemerintah dalam pencegahan pernikahan anak usia dini. Kasus yang diangkat adalah peran Lembaga Bantuan Hukum Asosiasi Perempuan Indonesia untuk Keadilan (LBH APIK) di Sulawesi
\end{abstract}


Selatan. Secara khusus, penelitian ini mencoba menganalisis model pembangunan jejaring internasional LBH Apik. Informasi awal menunjukkan bahwa untuk pelaksanaan agenda advokasi ini, pihak LBH Apik bekerjasama dengan Organisasi Non Pemerintah Internasional (ORNOP) atau International Non-Governmental Organization (INGO) yakni OXFAM. Penelitian ini merupakan jenis kualitatif dimana sumber data berupa informasi dan narasi yang diperoleh melalui wawancara mendalam, dan sumber dokumen. Penelitian ini menemukan bahwa; Pertama, aktifitas LBH Apik dalam upaya pencegahan pernikahan anak dapat dikategorikan sebagai upaya oleh NGOs untuk mengimplementasikan nilai-nilai human security. Kedua, strategi-strategi yang ditempuh oleh LBH Apik menunjukkan bahwa perubahan yang dituntut bersifat transformatif karena mendorong perubahan struktur sosial yang membuat posisi anak perempuan menjadi sangat rentan. Ketiga, kemitraan lokal, nasional dan internasional LBH Apik dibangun dari identitas kolektif sebagai pihak yang memperjuangkan pencegahan pernikahan anak.

\section{Kata Kunci: pernikahan anak; NGOs; LBH APIK; OXFAM}

\section{INTRODUCTION}

Child marriage is a problem that often occurs in Southeast Asia, the Middle East, Latin America, South Asia and Europe. Statistics show that around 12 million girls marry before their 18th year each year (Girls Not Brides Website, 2017). This situation makes child marriage a global issue that must be addressed collectively by the international community. For example, in the Sustainable Development Goals (SDGs), child marriage has been included as an agenda that shows the commitment of countries to overcome this problem. This was carried out as a continuation of the post-achievement of the Millennium Development Goals (MDGs) between 2000 and 2015. The global community's concern about the practice of child marriage relates to the fact that child marriage violates children's human rights, limits their choices and opportunities, and makes them vulnerable to violence, exploitation and abuse (UNICEF, 2017).

Child marriage makes the chain of poverty less likely to be broken because children no longer have access to education to compete for decent work. Even though the child's age should be a time for physical and emotional development before entering adulthood. Child marriage can be defined as the marriage of a girl or boy before the age of 18 and refers to both formal and informal marriages in which children under the age of 18 live with their partners as if they were married (UNICEF, 2017). In Indonesia, according to Law Number 35 of 2014 concerning Amendments to Law Number 23 of 2002 concerning Child Protection Article 26 paragraph 1 letter c states that parents are obliged and responsible to prevent child marriages. Globally, the practice of child marriage has actually decreased in various countries around the world. UNICEF in 2018 saw a decrease in numbers compared to ten years ago. It is estimated that 25 million child marriages have been prevented through various effective efforts. However, there are still around 650 million women and girls alive today who married before they turned 18 (UNICEF, 2018).

Although national regulations have explicitly prohibited child marriage, according to the UNICEF report, Indonesia is the country with the seventh highest rate of child marriage in the world, namely 457.6 thousand women aged 20-24 who were married before they turned fifteen (Vogelstein, 2013). Based on central statistical data, one in nine girls in Indonesia is married at less than 18 (BPS et al, 2020). In fact, Indonesia is in 2nd place of all ASEAN member countries. Although the trend of marriage for girls in Indonesia, both those who 
had their first marriage before the age of 18 and 15, showed a decline in the period from 2008 to 2018, the decline was still considered slow. Global and national trends related to child marriage have also been affirmed in South Sulawesi Province. South Sulawesi itself is included in 22 provinces with high child marriage rates in Indonesia. As much as $12.1 \%$ of child marriages occurred in South Sulawesi (PPPA, 2020). In 2017, based on symphony data from the South Sulawesi Women Empowerment and Child Protection Service (DP3A), there were 333 child marriages. A drastic increase occurred in 2018, reaching 700 cases or an increase of about 218 percent.

Until now, the number of child marriage cases in South Sulawesi has not decreased significantly. There has even been an increase in cases of child marriage during the COVID-19 pandemic. In South Sulawesi, during the pandemic, there were around nine cases of child marriage received by LBH APIK from three regions, namely Makassar City, Gowa Regency, and Pangkep. This is in line with data from the Indonesian Religious Courts that have received around 34,000 applications for dispensation of marriage submitted before they turn 19 . This is because many parents lost their livelihoods during COVID-19 and think that marrying off their daughters will be an economical solution. This is also exacerbated by the condition of learning activities carried out online so that children do not focus on carrying out learning activities and open up space for relationships outside of marriage. The family then is in a position of pressure so that they are forced to marry their children to avoid relationships that are not in accordance with religious teachings. Meanwhile, the provision of protection services cannot be maximized by LBH APIK Sulsel during this pandemic (Sain, 2020).

The current phenomenon of child marriage is not only responded to by the state but also by various parties, both state actors (Central and Regional Government) and non-state (Non-Governmental Organizations). In the elaboration above, the assumption built is that all actors involved in efforts to prevent child marriage can bring about changes locally / domestically. One of the active parties comes from the NGO group, namely the Legal Aid Institute for the Indonesian Women's Association for Justice (LBH APIK Website). LBH APIK Makassar realized a legal system with a women's perspective, namely a fair legal system seen from the pattern of power relations in society, especially the relationship between women and men by constantly trying to eliminate injustice, as marginalization or subordination in power relations, stereotypes (standardization of roles), physical, mental or sexual violence and excessive burden on one party (LBH APIK Website, 2020).

Based on this background, this study aims to identify and analyze the LBH Apik international network building model in handling child marriage cases in South Sulawesi. In particular, this study seeks to answer the question "How can LBH Apik start and mobilize international help related to the Prevention of Child Marriage in South Sulawesi?" This research is important to do as part of a major effort to map the potential contribution of each actor in responding to this problem. By mapping the potential contributions, in the future efforts to prevent early childhood marriage can be more effective and involve more parties.

Research related to child marriage in Indonesia in various fields of social science has been carried out. The most recent research in 2019 entitled Natural disasters and girl's vulnerability: is a child marriage a coping strategy of 
economic shocks in Indonesia? This study tries to analyze the phenomenon of increasing child marriage in disaster areas from an economic perspective. This study found that post-disaster economic constraints prompted many families to encourage their children to marry immediately in order to reduce the economic burden on the family (Dewi \& Dartanto, 2019). Research related to child marriage has also been carried out in the perspective of education and sociology. These studies are Effects of Social Habits and Girl-child Marriage on Students' Academic Performance in Social Studies (Titus et al., 2016) and Early Childhood Development in the Context of the Family: The Case of Child Marriage (Wodon, 2016).

Meanwhile, related to a more specific theme regarding NGO activities in protecting women and children in the Indonesian context, several previous researchers had also done it. In a study entitled Pro-women's policy advocacy movements in Indonesia (Poerwandari et al., 2018). This study presents an analysis of the activities of an NGO called the National Regulation of Pro Perempuan Network (JKP3) to carry out policy advocacy during the reform era. The research is based on literature reviews, observation and participation in various activities carried out by the network, and analysis of field notes and documents. In this research, it was found that these NGOs faced obstacles internally and externally. Externally, the obstacles faced are the lack of awareness and understanding of gender equality, and rejection of a pro-women perspective. This study also found that there are religious interpretations that limit the rights and roles of women, lack of bureaucratic concern, and overly political attitudes from members of the legislature. The internal constraints faced include the dynamics of working together in the network. This study emphasizes the identification of methods and strategies in implementing advocacy for the rights of women and children.

Other related research that has been conducted is entitled Feminist mobilization for policy change on violence against women: insights from Asia, Gender \& Development (Cagna \& Rao, 2016). This study explores and provides a comparison regarding how the women's movement in China, India, and Indonesia is mobilized to influence changing policies and regulations related to violence against women and children. This study tries to understand how the relationship between democratization and policy change for women and children, the role of the women's movement and the various challenges it faces. From these studies, there is no research that specifically tries to elaborate how NGOs carry out their advocacy in child marriage cases by mobilizing support and resources from abroad, or with international NGOs. Based on these thoughts, the proposed research will examine the International Network Development Model by NGOs in advocating for child marriage problems in Indonesia. As an analysis knife, this research will use the concept of Human Security (human security), Transformative NGO, and Collective Identity. The following is an elaboration of the three theoretical approaches.

\section{RESEARCH METHODS}

This research was conducted in South Sulawesi Province with a qualitative approach. Qualitative research includes research and collection of various kinds of empirical material such as case studies, personal experiences, introspective, life stories, interviews, observational, historical, interactional, and visual texts 
(Denzin \& Lincoln, 1994). Data were collected through documents, in-depth interviews, and focused group discussion (FGD). The informants of this study were activists of LBH Apik, International Partners (OXFAM), local partners and the City and Provincial Governments. Data processing begins with selecting data related to research, compiling data, classifying data as an effort to classify, classify, and sort data based on certain classifications determined by the researcher. Namely processing classified data, then the data is analyzed and continued with preparing papers based on data that have been prepared logically and systematically. The data analysis technique in this research is descriptive argumentative, which looks at the social traditions that are realized in the perspective of the beliefs of the research object. The next step, the researcher concludes that contains the essence of the entire series of research activities and the presentation of research results.

\section{RESULT AND DISCUSSION}

\subsection{LBH Apik and Child Marriage Issues through a Human Security Perspective}

Although there are various definitions put forward by several experts in the literature on human security, all of them have similarities in the concept of security, which is more oriented towards protecting individuals / humans than against the state. Here there is a common perception that the greatest threat to humanity comes not only from military attacks but social, economic and environmental problems that will worsen the conditions of human life. Another significant development is that security is no longer dominated by the discipline of Security Studies, but Human Security is a multi-disciplinary approach that views security issues as a study issue involving many disciplines such as International Relations, Development Studies, Strategic Studies, Public Administration and various other disciplines. This multi-disciplinary approach is caused by the complexity of the problems studied and human security to be the intersection of connecting social, economic, humanitarian, human rights and environmental issues to create security and reduce human suffering (Burhanuddin, 2017). This theory will analyze the motives of LBH Apik in advocating for child marriage problems in Indonesia.

Implementing human security is no longer focused only on the state but also by NGOs (Sarah, 2002; Richmond, 2010; Smith and Whelan, 2008; Asyari et al, 2020). Globally, NGOs can implement human security because of several factors, namely increasing number and coverage, having the capacity, experience and desire to respond to social and political problems, both national and transnational. Even though they can implement human security, NGOs still face several limitations such as funding, dynamic relationships with the government, and multidimensional challenges from human security problems (Sarah, 2002). This study found that the activities carried out by LBH Apik as an NGO are part of the effort to implement human security, especially the protection of children and adolescents. Currently, child marriage has become an issue that is being discussed both locally and globally.

The wider concept of human security has made child marriage a human right can be classified as a case study. Several non-state actors are also directly involved in overcoming this problem. One non-governmental organization that focuses on addressing child problems in South Sulawesi is LBH APIK Sulsel. 
Historically, the establishment of the Indonesian Women's Association for Justice (APIK) can be traced back to 1995. The association then developed and established the APIK LBH (Legal Aid Institute) whose working area includes 16 offices in the Indonesian Territory. In carrying out its activities, APIK takes on the role and function of a facilitator (communication, coordination, support system), mediator (member conflicts, cooperation with other parties, deviations from vision-mission, values), planning, monitoring and evaluation related to the Association program. LBH APIK Indonesia in the level of regions provide information and documentation centers and knowledge management, organizers of capacity building and advocacy networks at the national level (LBH APIK Website, 2020).

In South Sulawesi, LBH APIK Makassar has been formed and active since 2002. In 2017, LBH APIK Makassar transformed into LBH APIK Sulsel because of the need for a wider working area. Specifically, LBH APIK focuses on problems or issues of women and children who experience violence and discrimination. This is a form of strengthening the women's movement as part of the civil society movement in empowering gender-just laws. Early childhood marriage has become an intense concern of LBH APIK Sulsel, given the statistical data that shows the practice of child marriage still occurs in South Sulawesi. For example, LBH APIK South Sulawesi carried out a specific program on the Prevention of Child Marriage, entitled Creating Spaces: End Violence against Women and Child Marriage. This program aims to create space to reduce violence against women and girls and reduce the practice of child marriage in South Sulawesi. This program is implemented in three districts / cities, namely Makassar City, Gowa Regency and Pangkep Regency (Sain, 2020).

According to LBH APIK's records, the increase in the number of child marriages in South Sulawesi is quite alarming. This view is in line with data from the South Sulawesi Women's Empowerment and Child Protection Agency (DP3A) in 2017 which recorded 333 child marriages. A significant addition occurred in 2018 , reaching 700 cases. In the view of LBH Apik, the vulnerability faced by children then receives threats from the increasing phenomenon of child marriage. In the concept of human security, as an NGO, LBH Apik has conducted securitization of child marriage cases by positioning the phenomenon of child marriage as a threat to human security.

\subsection{LBH Apik's Strategy as a Transformative NGO in Preventing Child Marriage in South Sulawesi}

In a study related to NGOs and Social Movements, one attempt to construct an alternative way of looking at the topology of social movements and their organizations was proposed by Mansour Fakih. Fakih (1998) constructs the theory of social movement organization as a counter-hegemonic movement. The NGO movement is put in a process of transformation, namely creating new and better relationships. Fakih classified NGOs into three types; First, Conformists who are characterized as NGOs with a caritative paradigm. Second, Reformers, namely their paradigm, have no tendency to make structural changes. And the third is Transformative, which is an NGO that substantively questions the mainstream paradigm and ideology in it and tries to find an alternative paradigm that will change the structure and superstructure that is detrimental to the marginalized (Baharuddin, 2015).In this study, the transformative NGOs theory 
approach was used to explain the basis for choosing the LBH Apik strategy in advocating for child marriage issues. This study affirms that LBH Apik can be classified as a Transformative NGO.

According to LBH APIK, there are six factors driving child marriage in South Sulawesi. First, Gender Status Inequality in society, which places girls in a lower position than boys. This makes it difficult for girls to resist their parents' wishes, which prompted them to marry an older man. Second, there is a lack of knowledge about the health risks that occur because of young marriage, the high postnatal mortality rate, premature babies and the risk of getting HIV / AIDS. Third, in conflict areas, the practice of child marriage is more rampant because of the collapse of the legal, economic and social structures. Many families who migrate choose to marry off their daughters because life options are very limited in the refugee camps. This is in line with the findings of Dewi \& Dartanto (2019) stating that in Indonesia, India and Sri Lanka, child marriage has increased because of forced marriage after the tsunami, or sometimes, marriages were carried out to get special help for those who are married.

Fourth, people who migrate for economic reasons. When men lose their land of work for industrialization in agriculture, women are forced to become breadwinners. Girls are finally encouraged to marry young to reduce the burden on the family. Several previous studies by UNFPA and UNICEF have shown that poverty is a major driver of child marriage in developing countries. Girl marriage is considered solving escape poverty (BPS et al., 2020). Fifth, culture / habits, where old parents were married at the age of their children, they lived happily and wanted to continue this tradition by marrying off their children at a young age. Several traditions that perpetuate child marriage are still found in Indonesia. Credos Institute research shows how the socialization of gender roles affects society's acceptance of child marriage. In research conducted in Makassar and Gowa, girls who are late in marriage are referred to as old maids (BPS et al, 2020).

This makes girls prefer to marry at an early age in order to avoid the bad stigma of society. Sixth, social factors, namely uncontrolled association, parental control that is not optimal on children's behavior. Research on marriage dispensation in three regions shows that the highest reason for applying for marriage dispensation is for parents' concerns about their children who are already dating or engaged (Girls Not Bride Website, 2019). The factors that have been elaborated above, then become problems of concern for LBH Apik.

In overcoming the problem of child marriage, LBH APIK implements five key strategies. First; Increased Knowledge and Capacity to Influence Policy Making and Advocating for Applicable Regulations to Reduce Violence against Women and Girls (KTP / AP) and Child Marriage. This program includes socialization and campaigns to end violence against women and girls in communities, schools and other public places. Capacity building for child marriage prevention and KTPA was also carried out to key figures in the community, government, youth groups and networks. Second; Promote Changes in Behavior and Social Norms among Adolescents to reduce KTP / AP and Child Marriage. Besides socializing among adolescents, LBH APIK Sulsel also conducts outreach to parents to increase supervision of children through parenting or family education. So that social norms can be understood together among the community and can change the 
behavior of promiscuity that occurs between adolescents and parents to carry out their function optimally as child supervisors.

Third; Strengthening the Skills and Capacity of Women and Girls Leaders to Understand their Rights and take part in Reducing KTP / AP and Child Marriage. This is done by appointing Change Agents in several schools as a model for preventing child marriage. The socialization of the impact of child marriage through sexuality and reproductive health education in schools is also carried out so that children understand the dangers of early marriage practices. Fourth; Increase the Capacity of Partners to Implement the Prevention Program for KTP / AP and Child Marriage. Capacity building to prevent child marriage was also carried out for key figures in the community, government, youth groups and the LBH APIK South Sulawesi network.

Fifth; Conducting joint campaigns to Stop and Prevent VAW / AP and Child Marriage through public dialogue, print and electronic media, making campaign brochures and souvenirs. Campaigns on social media are also carried out by involving children / adolescents / children's forums by identifying social media that are most often used by children / adolescents to convey messages through social media with several taglines for preventing child marriage. For example, delay marriage to continue school. Another form of campaign is carried out by making a short film entitled Titik Buta, which tells the story of the tendency of people to practice child marriage because it has been a long tradition.

To implement this strategy, there are four obstacles faced by LBH APIK Sulsel in advocating for the prevention of child marriage. First, the community is unprepared because it collides with a culture / habit that has been going on continuously. Therefore, the approach that must be taken is a persuasive approach by conveying some affects of child marriage to the community. Second, the practice of child marriage is often carried out by parents because there is an inherent power relationship between the child and the parent. Sometimes, the practice of child marriage is also supported by elements such as religious leaders, local government therefore the role of government is needed through policies / regulations regarding the prohibition of early childhood marriage and applies to the smallest level such as Village Regulations (Perdes).

Third, not all regions have policies to prevent child marriage, especially in rural areas. So that this preventive policy needs to be introduced with the policies that have been successfully practiced in other regions. Fourth, the number of child marriage cases in South Sulawesi is too large and is inversely proportional to the human resources available. The resolution process has been slower because of limitations in going directly to the field. From the elaboration of the strategy above, it can be concluded that the problems addressed by LBH Apik related to child marriage are not only centered on actors but also on social structures or systems that make girls very vulnerable. Therefore, the strategy proposed is not only charitable and encourages changes in actor behavior, LBH Apik further struggles to carry out transformations in social structures that are detrimental to girls. Based on these findings, LBH Apik can be categorized as a Transformative NGO.

\subsection{LBH Apik International Network in Preventing Child Marriage in South Sulawesi}

This section will explain about LBH Apik's efforts to develop international networks with a collective identity approach. One of the theoretical explanations 
of collective identity is proposed by Alberto Melucci, who argues that collective identity is forming a system of action. This collective identity results from interactions and shared ideas carried out by several individuals or groups about the orientation of an action and the opportunities and challenges of implementing that action. Interacting and sharing makes Melucci define collective identity as a process. Because through this identity is then constructed and negotiated (Johnston \& Klandermans, 1995; Baharuddin et al., 2020).

A similar explanation was also conveyed by Porta and Diani, who said that collective identity can also be formed based on goals, values, behavior, paradigms and ways of life and experiences of collective action. Sometimes, identity becomes very exclusive and ignores various other forms of identification, but more often, identity is operated in an inclusive and diverse manner, such as individuals who feel close to several collective identities (Porta \& Diani, 2006). From the two explanations above, we can see that this collective identity is built from a common goal and perspective. It was built with the pretense of being a system of collective action.

In carrying out these programs, LBH APIK cooperates with several governments or non-government actors as partners. The government becomes an actor that can change policies and legal systems that are gender-just and socialize norms to prevent the practice of child marriage. In several dialogues or public discussions, LBH APIK South Sulawesi also invited the government as a resource or provided recommendations for the smooth running of the program of activities. Non-government actors are also involved by LBH APIK to run several programs. For example, the Creating Spaces program: End Violence against Women and Child Marriage is supported and supported by OXFAM Indonesia.

Until now, LBH APIK South Sulawesi has never collaborated with private companies. But it is possible that this collaboration will be implemented later. Implementing LBH APIK activities is mostly carried out by LBH APIK itself, although it still involves several actors in implementing several other parts of the activities as described above. This may be because the activities carried out by LBH APIK are more in advocacy. The involvement of non-government actors is found in the agenda of outreach activities, seminars, and public discussions that require financial help.

Meanwhile, the involvement of government actors is found in several outreach activities and also in advocacy activities. The government is needed as a legal force to guard cases of abuse, violence, or early child marriage. The rest, most child marriage prevention activities are carried out by LBH APIK using their own resources. This research found that, to build partnerships both locally, nationally and internationally, LBH Apik built relationships based on an idea related to efforts to save the future of children through preventing child marriage. The idea then transformed into a collective identity that made local, national and international partners have proximity and cohesiveness with LBH Apik.

\section{CONCLUSSIONS}

This research concludes three things; First, LBH Apik's activities in efforts to prevent child marriage can be categorized as an effort by NGOs to implement human security values. Second, the strategies adopted by LBH Apik show that the changes required are transformative because they encourage changes in the social structure that make the position of girls very vulnerable. Third, the local, 
national and international partnerships of LBH Apik are built on a collective identity as the party fighting to prevent child marriage.

\section{REFERENCES}

Girls Not Brides. 2017. How ending child marriage is critical to achieving the Sustainable Development Goals https://www.girlsnotbrides.org/wpcontent/uploads/2017/06/Child-marriage-and-achieving-the-

\section{SDGs_DAC.pdf}

Unicef Indonesia. 2017. Research Brief: Progress on Pause: An Analysis of Child Marriage Data in Indonesia Child Marriage in Indonesia (2013 and 2015).

Vogelstein, Rachel B.. 2013. Ending Child Marriage (2013). Council of Foreign Relations.

Dewi, Luh Putu Ratih Kumala \& Teguh Dartanto (2019) Natural disasters and girls vulnerability: is child marriage a coping strategy of economic shocks in Indonesia?, Vulnerable Children and Youth Studies, 14:1, 24-35, DOI: $10.1080 / 17450128.2018 .1546025$

Wodon, Quentin (2016) Early Childhood Development in the Context of the Family: The Case of Child Marriage, Journal of Human Development and Capabilities, 17:4, 590-598, DOI: 10.1080/19452829.2016.124527

Titus, Adesegun Benedict, Adekunle Babatunde Dada \& Emmanuel O. Adu (2016) Effects of Social Habits and Girl-child Marriage on Students Academic Performance in Social Studies,Journal of Sociology and Social Anthropology, 7:4, 250-255, DOI: 10.1080/09766634.2016.11885723

Poerwandari, Elizabeth Kristi, Ratna Batara Munti \& Jackie Viemilawati (2018) Pro-women's policy advocacy movements in Indonesia: Struggles and reflections, Asian Journal of Women's Studies,24:4, 489-509, DOI: 10.1080/12259276.2018.1538646

Cagna, Paolo \& Nitya Rao (2016) Feminist mobilisation for policy change on violence against women: insights from Asia, Gender \& Development, 24:2, 277-290, DOI: 10.1080/13552074.2016.1194035

Burhanuddin, Agussalim. 2017. Studi Keamanan dan Isu-Isu Strategis. Penerbit Universitas Hasanuddin: Makassar.

Baharuddin, Aswin (2015) Resistensi Koalisi Organisasi Non-Pemerintah untuk Keamanan Pangan dan Hayati terhadap Program Penanaman Benih Transgenik Monsanto di Indonesia. Jurnal Wanua: Jurnal Hubungan internasional Universitas Hasanuddin

Johnston, Hank \& Bert Klandermans (ed.). 1995. Social Movements and Culture. Minneapolis: University of Minnesota Press.

Porta, Donatella Della \& Mario Diani. 2006. Social Movements: An Introduction (second edition). USA: Blackwell Publishing.

Smith, Michael G \& Whelan, J. (2008). Advancing Human Security: New Strategic Thinking for Australia. Security Challenges,4(2), 1-22. Retrieved January 6, 2021, from https://www.jstor.org/stable/26459139

Sarah Michael. (2002) The Role of Ngos in Human Security. Available at SSRN: https://ssrn.com/abstract $=351240$ http://dx.doi.org/10.2139/ssrn.351240

Oliver P. Richmond (2003) Introduction: Ngos, Peace and Human Security,International Peacekeeping, 10:1, 2-11, DOI: 10.1080/714002400 
Baharuddin, A., Lubis, A., Lubis, M., Fahira, F., Rahmatia, R., \& Firdaus, F. (2020). Analyzing Transnational Relations of Local Literacy Groups through the Collective Identity Approach. http://dx.doi.org/10.4108/eai.21-102019.2291524

Badan Pusat Statistik, PUSKAPA \& Unicef (2020). Prevention of Child Marriage: Acceleration That Cannot Wait.

Asyari, M.S., Baharuddin, A., Lubis, A., Guntur, N.O., \& Wirapraja, M.S. (2020). Problem of East Timorese Stolen Children in Indonesia:A Human Security Perspective. http://dx.doi.org/10.4108/eai.21-10-2019.2291521

Interview:

Rosmayati Sain (Director of LBH Apik Sulawesi Selatan) July 9, 2020 